\title{
An "Other" of One's Own \\ Pre-WWI South Slavic Academic Discourses on the zadruga $^{1}$
}

NATASCHA VITTORELLI

Since the beginning of the nineteenth century, the concept of zadruga has attracted the interest of many writers and scholars - South-Eastern as well as Western European and North American. ${ }^{2}$ These scholars have constructed and re-constructed the zadruga as a rural South Slavic form of familial organization, or "South-Eastern" as it has more recently (after 1945) been termed. Since then the zadruga ${ }^{3}$ has stood - from a South Slavic or Yugoslav point of view in different variations of opposition to its "Other," which was Western Europe, or to be more precise, to what was thought to be a Western European familial constellation.

INVENTING A WORD, INVENTING A TERM

The person credited with having invented the neologism zadruga is the Serbian ethnologist and language reformer Vuk Stefanović Karadžić (1787-1846). ${ }^{4}$ Valtazar Bogišić, one of the pioneers of zadruga research in the nineteenth century, argued that Karadžić was mistaken when he introduced the word zadruga in his Serbian-German-Latin dictionary. Bogišić, whose account of the zadruga will be discussed presently, was convinced that the noun zadruga had never existed and that, since Dušan's code in the fourteen century, the word kuća (Serbo-Croatian for house) had been used to name a household or family, not unlike in other parts of Europe. According to Bogišić, people added the adjective zadružna if they wanted to express that a household had enough workers at its disposal; if this was not the case, a household or a family would be called inokosna (kuća). ${ }^{5}$ The word zadruga seems to have been recorded for the first time in the first edition of Karadžić's dictionary of 1818 :

3aApyra, f. Hausgenossenschaft (im Gegensatze der einzelnen Familie), plures familiae in eadem domo (more Serbico). (Karadžić Srpski rječnik 191)

The second edition of Karadžić's dictionary, printed approximately 35 years later, supplied the entry on zadruga with the following ethnographic comment:

As I have heard in Serbia, thirty housemates share one house; but in Kosovo in Dalmatia a man from the village of Ridjani was shown to me, his surname being Trifunović, who had sixty-two housemates, among them thirteen married women and two widows. For Christmas and the Patron Saint holiday or when one of them marries, ${ }^{6}$ they all gather, otherwise they live in the mountains or on the fields, the house-father mostly in 
the mill. This house owns around 1,400 goats and sheep, up to fifty cattle and fourteen horses [...]. (Karadžić Srpski riječnik 173) ${ }^{7}$

According to Karadžić, the members of a zadruga supported themselves with farming and stock-breeding and did not necessarily live in the same place. Women were acknowledged only when married or widowed, while the head of the household was mentioned casually without referring to any of his tasks or duties specifically.

Karadžić did not only "invent" the word zadruga. With his commentary, he added further substance to the idea that a zadruga was an extended family, thereby contributing to the dominant cliché-ridden perception of the zadruga that has persisted until today. This perception of the zadruga as a "patriarchal Balkan extended family" is the starting point of this paper. I have selected four publications, which appeared between the middle of the nineteenth century and the First World War, and which I will use here to demonstrate the main tendencies by which a "South Slavic Self" has been constructed as an own "Other" - in opposition to "the West."

In chronological order, the authors of the four texts are Ognjeslav Utješenović, ${ }^{8}$ Valtazar Bogišić, ${ }^{9}$ Ivan Strohal ${ }^{10}$ and - the only female author Ljubiza Rakitsch (Utiešenović; Bogišić De la forme; Strohal; Rakitsch). With the exception of Rakitsch, I have chosen these works because of their influence and importance among scholars both in the SHS-state and in socialist Yugoslavia. ${ }^{11}$ Rakitsch's dissertation (at the University of Zurich and later published) was included because it is the only text on the zadruga composed by a woman in this period and has hardly received any attention in zadruga research so far. ${ }^{12}$

Zadruga discussions have been very much bound up in processes of establishing a South Slavic/Yugoslav national identity; these processes I understand as both polyvalent and contradictory. The example of the zadruga expounds the contradictions in processes of nation formation on two levels: firstly, by demonstrating existing ambivalences within the respective texts I have chosen, and secondly, by comparing these texts with each other. Therefore, I will first present the contents of the four texts and contrast the contradictions among them. Then I will expand on three "typical" features of the zadruga that can be arranged - in the framework of stereotypical perceptions - into three dichotomies: the Balkans versus Western Europe, the extended family versus the nuclear family, and, finally, the patriarchal versus the non-patriarchal.

My intention is not to determine what the zadruga might have been or what it was (e.g. rather an extended family than a nuclear one, etc.), but to show the zadruga as a contested site, "where crucial political and cultural contests are enacted and can be examined in some detail,"13 and thereby provide insight into the main threads of South Slavic academic writing on the zadruga from the middle of the nineteenth century until 1914. 
UTJEŠENOVIĆ: SOUTH SLAVIC HAUSKOMMUNION

\section{AS A MODEL FOR THE WEST}

In 1859, Ognjeslav Utješenović (1817-189o) published the first monograph on the topic of the zadruga. ${ }^{14}$ The book came out in Vienna and was written in German. To legitimate his project, Utješenović argued that he had himself grown up in what he called a Hauskommunion. This term, which is now out of date, was quite common for describing a zadruga in German at that time, as was the more self-explanatory Hausgenossenschaft. The Hauskommunion intimately known to Utješenović was located in the Croatian military frontier, where Utješenović's father had served as a sergeant (Utiešenović 25), and the author's personal experience seems to have served as his main source of information.

By showing the advantages as well as the disadvantages of the Hauskommunion, Utješenović wanted to prove that he was "not one-sided and surely not prejudiced by narrow-minded local patriotism or caught up in the fog of historically sentimental memories" (Utiešenović 966 .). ${ }^{15}$ Nevertheless, the picture he paints of the Hauskommunion is one of a romantic rural idyll:

Commonly in a veritable grove of fruit trees stands a small house, in which there is usually a hall, from which one enters the kitchen or the area of the fireplace, as well as spacious rooms to the left and to the right, which are furnished comfortably and tidily in wealthy places but very miserably in poor ones. [...] Living in such a house, which bears the Christian name of the house-father and one single surname, one usually finds:

1) a sprightly house-father (gospodar, starešina) about 40-50 years old, with a wife and 2-3 children; he is entrusted with the position of house administrator, while his wife is responsible for the inner household;

2) his 60-70 year-old parents; the father used to serve as the house-father before he was relieved of this burden;

3) his father's brother and wife, with or without children;

4) a younger brother of the house-father and his wife;

5) another younger brother, who is absent, for example, due to military duties.

Next to the house are farm buildings, including a stable where different types of livestock [...], the farming equipment and household tools are kept.

The piece of land has $25-40$ yokes in more or less scattered parcels as mixed crops prevail. (Utiešenović $18 \mathrm{f}$.) ${ }^{16}$

In the course of his discussion of the Hauskommunion, Utješenović does not live up to his stated intentions, however - in the foreword he declares he would not obscure the disadvantages of this type of household organization, but he mentions not one single possible weakness of the Hauskommunion. ${ }^{17}$

What Utješenović was interested in was correcting common misconceptions about the number of people living in Hauskommunionen. He reckoned their average size to be between ten and twelve members, noting that even "single families" could be found. According to Utješenović, the inner organization 
of the Hauskommunion was based on a gendered division of labor: household work - cooking and baking bread as well as looking after the children, milking the cows and feeding the domestic fowl - was a responsibility of the housemother, usually the wife of the house-father. In some areas women would take turns in household-duties. The remaining women, if not too old or brides in their first year in the new Hauskommunion, joined the men working in the fields. Mothers of newborns took their babies, including the cradles, with them in order not to waste time returning home to breast-feed the children (Utiešenović 21-25): "Work is a feast; there is singing all day and, in the evenings, when one would expect people to be tired after a long summer day's work, the merry young folk start a kolo-dance" (Utiešenović 22). ${ }^{18}$ In an attempt to prevent criticism of his avoidance of the term "patriarchal" in connection with the Hauskommunion, Utješenović argued that it was not a "patriarch" whose word was law in the Hauskommunion, but rather it was the responsibility of the house-father to behave more like a "house administrator" (Utiešenović 53). Utješenović noted that every Hauskommunion had a family council that reached decisions the house-father was obliged to follow. He did not remark on who was allowed to serve on this council, which would only assemble when highly important decisions were on the agenda. Generally, the co-inhabitants would rely on the judgment of the house-father.

Twelve hundred years of unbroken continuity notwithstanding (as established by Utješenović), he characterized the Hauskommunion as a progressive institution well suited to combat the impending impoverishment of the Southern Slavic peasantry (Utiešenović 17). He described the Hauskommunion as one of four dominant European agrarian models, the others being the French, the English and the Russian. By this, Utješenović did not just mean to grant the "Christian-Slavic people"19 living in Hauskommunionen an equal place among the civilized European nations. He went one step further, extolling the intactness of the South Slavic type of family and recommending it as an example that the West - in the face of the increasing onslaught of individualism - would do well to learn from.

BOGIŠIĆ: ZADRUGA VERSUS INOKO $\check{T I N A}$

In 1884, Valtazar Bogišić's (1834-1908) treatise on the zadruga was published in France. It began with a page-long enumeration of works on the topic (Bogišić De la forme). He displayed unconcealed pride in the zadruga because it, unlike any other (South-) Slavic social institution, had been capable of attracting the attention of so many Western academics. Nevertheless, the author questioned the "scientific exactness" of these Western works as almost all of them tended to neglect the existence of another family type: the inokoština or single family, 
which consisted of "père, mère et enfants" (Bogišić De la forme 9). If mentioned at all by these authors, the inokoština was treated as the opposite of the zadruga. According to Bogišić, the fact that these writers could only define the zadruga as the (rural) antithesis of the inkostina was due to the inability of foreigners to adequately grasp the "substance" of a specific South Slavic phenomenon. They defined the zadruga and the inkoština merely by their number of family members and thereby failed to identify the identical internal organization inherent to both. The zadruga and the inkoština were simply, according to Bogišić, two different stages, two basic phases, of the rural South Slavic family (Bogišić De la forme 40).

However, in concentrating on refuting the polarization of the inkoština and the zadruga, Bogišić created new antipodes by comparing these two forms with the "urban family type," which he considered to be similar in its essence throughout Europe. In Bogišićs typology of forms of familial organization, he also briefly acknowledged the existence of a fourth family type: "la famille musulmane," whose main deviations were "religious elements," of which "optional polygamy" was the most important. Bogišić declared the "Muslim family type" useless for his project since this sub-model could always be deduced from one of the other three family types. He also admitted that he did not have enough data on this specific family type and was mentioning it merely for the sake of completeness (Bogišić De la forme 11f.).

One of the main differences Bogišić drew between zadruga/inkoština and urban familial constellations was in the father's position. In the urban family, he pointed out, the father alone made all decisions affecting the family. During his lifetime as well as in the case of his death, the father alone determined what was to happen to the family's property, and after his decease the possessions were divided. The father could by no means be released from his functions, and with his passing away the urban family itself also, in a manner of speaking, died. The zadruga, however, set clear bounds to such "patriarchalism." The starešina (the house-father or head of the family) was not able to decide anything without the agreement of the other adult co-inhabitants. Neither during his lifetime nor by virtue of his will could the zadruga house-father dispose over the zadruga's joint property as each male adult housemate always had the right to claim his part of the collective possessions. The death of the house-father did not initiate major changes; a successor was appointed, but no separation of property followed (Bogišić De la forme 12f.). Still Bogišić had to concede that in a temporary rural single family - and the inkoština represented nothing else - the competencies of the house-father were necessarily different (Bogišić De la forme 29).

Like Utješenović, who at the end of his volume offered a few suggestions for a practicable Hauskommunion law, Bogišić examined valid laws concerning the 
zadruga. The Serbian civil code of 1844 had caused confusion regarding understandings of the "nature" of the zadruga and the inkostina because it borrowed from Western laws, whose basis was the urban family type. Bogišić interpreted the Croatian laws from the years 1870 and 1874 as identifying the inkoština with the urban family type. That it had come to this he attributed to the tendency towards the standardization of family types: the urban nuclear family symbolized the civilized development to which the zadruga was supposed to stand in opposition. According to Bogišić, the lively discussion about the zadruga among academics and lawyers had reached a point where regulatory measures for, or even suppression of, the zadruga needed to be sought. In contrast, Bogišić defended the zadruga and pleaded for its preservation and continued existence. Seeing it as a well-organized family, he ascribed to it the function of the first and best moral school and rejected the assumption that individuals in the zadruga had no say.

\section{STROHAL: “THE FAIRY-TALE OF THE GOOD OLD DAYS”}

Twenty-five years after Bogišić's work, Ivan Strohal (1871-1917) turned his attention to the zadruga. He vehemently rejected what he called the "fairy-tale of the good old days," according to which the principle of communal property - once known to all Indo-European peoples - was preserved by the Southern Slavs in the form of the zadruga. According to this fairy-tale, the peoples of the Occident were not completely incapable of living with such an institution as existed among the Slavic nations; they were just "spoiled" and had to improve. This improvement, this regeneration of the Western peoples, would have to be carried out by the Eastern Slavic nations, and not by their governments but by the "unspoiled" Slavic people themselves (Strohal 226). ${ }^{20}$ Strohal accused those believing in this fairy-tale of romanticism.

This accusation and his earlier rejection of Herder's writings notwithstanding, Strohal himself drew on a romanticist notion of "good" Slavic qualities, which he even managed to successfully connect to the zadruga. The "essence" of the Southern Slavs could not possibly preserve the concept of communal property; this institution was rather a "fruit of the mild, altruistic nature of the Slavs [...]" (Strohal 229). ${ }^{21}$ From Strohal's point of view, this achievement guaranteed the Southern Slavs a status among the "civilized peoples," i.e. those in possession of elaborate law systems. Thus, his initial rejection of romanticism is promptly followed by national excessiveness. For all intents and purposes Strohal described the zadruga as an achievement of a deprived South Slavic peasantry, which manifested the "Slavic national spirit" (Strohal 273-5).

Strohal also considered the number of family members living in the zadruga. While earlier assumptions had claimed that a large number of inhabitants was the essential distinctive feature of this family type, he concluded that these were 
often exaggerated. He also showed a great interest in the legal aspects of the topic, agreeing with Bogišić's estimation that "bigger families and smaller ones" were founded on the same legal principles (Strohal 218). After Strohal zadruga or inkoština formed a "juristic person," which concurrently signified the main difference between them (gemeint ist $\mathrm{z}$ und $\mathrm{i}$ ) and the family types civic codes usually were grounded on:

[...] the property belongs neither to any one particular person who lives on it and farms it, nor to all of them together, but solely to the specific purpose of the whole property as a special juridical person. [...] Neither the house-father nor any other housemate but rather the whole family as a juridical person [is] the owner of the zadruga's property [...]. (Strohal 243f.) $)^{22}$

To Utješenović's and Bogišić's concerns over the unfavorable influences of the new civil codes on the structures of the zadruga and the inokosstina, Strohal added lamentations on the consequences of censuses. In general, the persons conducting censuses judged quite arbitrarily which households made up zadruge and which did not. Usually, the determining criteria for this decision were based on the number of inhabitants. As a result, relatively many households were categorized as single families, to which the zadruga law did not apply.

Strohal did not directly comment on the issue of patriarchism in zadruge, but when listing the expressions used to name them, besides the terms "kuća," "obitelj" and "familija" (the latter both meaning "family") he included the designation "patriarkalni život" ("patriarchal life") but did not expand on it (Strohal 217f.). In the historical development of the zadruga the once absolute power of the house-father, which used to include the ability to expel or even sell housemates, was restricted. As Strohal hastened to stress, this absolute power of the house-father was not a specifically South Slavic phenomenon but was known to all "Aryan peoples" (Strohal 256).

\section{RAKITSCH: SADRUGA AS THE MANIFESTATION OF A LOWER CIVILIZATION}

My research has shown that the first work on the Sadruga (sic) written by a female author was published in 1914 by Ljubiza Rakitsch (born 1884). The text in question is the dissertation Rakitsch wrote in the Department of Pedagogy at the University of Zurich (Rakitsch). Rakitsch limited her observations to the Serbian Sadruga under Ottoman rule. According to her, co-habitating in Sadruge had offered Serbians necessary protection in this period. Rakitsch's approach is structured by hierarchical views which relate simple family organizations to lower developed cultures and complex family arrangements to peoples of higher standing, and the poles of "lower" and "higher" cultural conditions co- 
incide with the symbolic geography of Eastern and Western Europe. The place assigned to the Serbs is that of a people at an inferior stage of civilization compared to Western European nations. Consequently the family type common to such a people is a necessarily simple one; nevertheless, Rakitsch claimed to have been able for this very reason to identify a number of "correspondences" between Sadruge and "old German clans" (Rakitsch 11). However, as she did not specify any of these correspondences, this parallel remains mysterious. With Serbia's increasing independence from Ottoman rule during the nineteenth century, she argued, Western European cultural influence increased, and the Sadruga lost its original protective function, a development that she seems not to have regretted at all.

Given the comments of Utješenović, Bogišić and Strohal on the "nature" of the Hauskommunion or zadruga, some may find Rakitsch's general description of the Sadruga surprising because of the number of family members she credited the Serbian Sadruga with and because of her labeling it not only an "extended family" but also "patriarchal":

Sadruga [sic] designates an association of a number of families linked by consanguinity to an extended family with common property. The Sadruga not rarely includes more than 40 or 50 members. [...] The Sadruga altogether displays the character of a patriarchal family type. At the head of the entire family was the chief, commonly the oldest member - called Starešina or Domaćin. (Rakitsch 14$)^{23}$

Rakitsch analyzed in detail "the position of woman in the patriarchal Serbian family, which stood in stark contrast to more developed cultures"(Rakitsch 17). ${ }^{24}$ The domestic, private sphere was the women's domain, while they were excluded from any access to the public. Women in the Sadruga were to be modest, obedient, subservient and obsequious. Foremost, they were required as laborers and mothers - preferably of sons - and enjoyed neither economic nor social rights, though as mothers of grown men, their situation could improve drastically. A woman could then be highly esteemed in her role as a respected adviser.

The house-father and his role in the Sadruga are outlined quite inconsistently in Rakitsch's dissertation. Although she identifies his duties as including the control and management of the family's affairs (the administration of earnings and expenses devolved upon him as did the representation of the Sadruga to the outside world), Rakitsch estimated his rights as “... quite limited. A slavish subordination of the other family members is out of the question" (Rakitsch 15). ${ }^{25}$ At the same time, however, she mentions the obligation of the housemates to "completely submit to the instruction of the house-eldest" (Rakitsch 15$)^{26}$ and touches upon the existence of a council only in passing.

Domestic education in the Sadruga was Rakitsch's main interest, and she divided it into physical care, moral, intellectual and aesthetic education. All 
of these she judged rather unfavorably from her Westernist standpoint: the hygiene as practiced in Sadruge did not meet the standards of modern hygiene; the virtues taught in Sadruge she marked "primitive"; many housemates were illiterate and the possibilities the Sadruga offered its inhabitants for developing taste remained unused. The only popular art form Rakitsch appreciated was Serbian folk poetry, and her regard of it was so high that she repeatedly cited verses as historical proof for her theses.

\section{COMPARIS ON}

The three highly stereotyped contested sites in which the zadruga is traditionally discussed will now be explored through a comparison of the four writers: "the Balkans," "the extended family," and "the patriarchal."

\section{The Balkans versus Western Europe}

Utješenović was interested in presenting the Hauskommunion as one of several equally valued types of the European agricultural model, but he also claimed that the Hauskommunion was able to offer Western Europe much more and should therefore be "exported" as the South Slavic model of the "whole house." ${ }^{27}$ Providing for the welfare and nutritional needs of all of its members as well as guaranteeing morality and low criminality, the Hauskommunion assured and preserved the intactness of the family - an intactness the West was, according to Utješenović, in danger of losing on account of rising individualism. He saw the existence and perpetuation of the Hauskommunion as threatened by the assumption of many Southern Slavs that everything native was inferior.

In a similarly anti-Western tone, Bogišić criticized the tendency of viewing urban nuclear families as a symbol of civilized development. He defended the persistence of the zadruga as a moral institution and complained about the disturbing outside alien influences, which prevented the continuation of untroubled family relationships in zadruge. Both Bogišić and Utješenović conceived of the Hauskommunion or zadruga as a future blueprint capable of solving all problems, and they both agreed that the Hauskommunion or zadruga were Christian family institutions with no space for Muslims. This again indicates the rather ambiguous position assigned to this specifically South Slavic family type towards the West. While the difference between many of its characteristics and those in the West was obvious, the Hauskommunion or zadruga still was not "Eastern" or "Oriental" enough to "accommodate" Muslims.

While Strohal protested against Western romanticism, he regarded the zadruga as a manifestation of the "South Slavic popular spirit." Strohal held the "positive character" of the Southern Slavs responsible for the existence of zadruge. He was also keen on assuring the Southern Slavs' status among the socalled "civilized peoples" - a status that, according to Strohal, could be proved 
by the elaborate legal system that existed in zadruge. Certainly Strohal contributed to the construction of a national myth, but he already seemed to anticipate the zadruga's inability to serve as a consumption and production unit in a modern industrial society.

Rakitsch was the only one of these four writers to completely reject the $\mathrm{Sa}$ druga. To her, everything Western European promised development, culture and civilization while everything Serbian was connected with pre-modern archaic primitiveness. However, even Rakitsch established a kind of link between Western Europe and the Sadruga by constituting an evolutionary model according to which the Serbian Sadruga, a "very old institution of the patriarchal stage of development" (Rakitsch 11), evidenced features the Germans with their clans had already overcome. Thus she foresaw the possibility that Serbian society would develop in a positive way (positive in her progressivist terms, of course).

\section{Extended Family versus Nuclear Family}

For Utješenović and Strohal there was no doubt that the Hauskommunion or zadruga was a type of family whose size was usually grossly overestimated. They attributed to the average Hauskommunion or zadruga only eight to eleven, or ten to twelve persons. This is all the more striking as zadruge are still repeatedly associated with the concept of the extended family. Estimates of the actual number of zadruga members vary significantly and can be as high as $150 .{ }^{28}$

Rakitsch presented quite the opposite view to that of Utješenović and Strohal. Explicitly using the term "Großfamilie" (extended family), she described families of forty to fifty co-inhabitants. Bogišić, who did not directly define the zadruga as an extended family, made quite clear in his typology that it must include more members than the inkoština and/or the urban nuclear family:

[Z]adruga [...] c'est-à-dire la communauté de la famille villageoise, qui se compose de plusieurs frères, cousins ou parents plus éloignés, avec leur femme et leurs enfants s'ils en ont;

La famille villageoise simple, ou il n'y a ordinairement que le mari, la femme et leurs enfants, [...] appelée [...] inokosna ou inokoština [...]. (Bogišić De la forme 11)

Two contradictory messages are communicated here: on the one hand, the zadruga did not essentially distinguish itself from "West European family types," which the author imagined as exclusively nuclear family types in terms of size. On the other hand, the concept of the Balkan extended family was confirmed.

\section{Patriarchal versus Non-Patriarchal}

Utješenović and Bogišić agreed that Hauskommunionen or zadruge did not deserve to be denoted as patriarchal. Both argued in a similar way: the house- 
father could not make decisions independently of the family council; therefore, the theory of the existence of a patriarch was untenable. At no point did they mention who had access to the family council, who made the decisions and how decisions were made.

According to Utješenović, women in Hauskommunionen had to cope with the typical double burden: working in the fields as well as doing the housework. However, neither this kind of gender-specific daily labor, nor the fact that it was women who left their zadruga to enter their husband's and men who stayed in the zadruga in which they were born (patrilocality!) were interpreted as signs of patriarchalism. Far more important is the fact that Utješenović's representation provides insight into the normative ideology of gender relationships in Hauskommunionen, which appears to have considered desirable at the time. ${ }^{29}$

Bogišić's complaints that lawmakers inspired by Western laws were misinterpreting the common law practiced in zadruge are in keeping with popular opinion, which held women responsible for the destruction of zadruge. These laws were said to have introduced an idea originally unknown in zadruga everyday life - the idea that a woman's dowry should stay in the private possession of women. Additionally, women's endeavors for emancipation, as well as their inability and unwillingness to live under one roof with their mothers-in-law and the families of their brothers-in-law, were believed to contribute to the perceptible decrease in numbers of zadruge. As already mentioned, Strohal avoided commenting on this question, but he did use "patriarkalni život" as an alternative term or synonym for zadruga, without further elaborating on it.

Rakitsch vehemently contradicted Utješenović and Bogišić. She was the only author to explicitly identify the position of women living in Sadruge as a central theme. She had no difficulty ascertaining the patriarchalism in Sadruga that, above all, was manifest in women having absolutely no kind of economic or social rights. Customs reflected this subordinated position of women in the $\mathrm{Sa}$ druga. Women were obliged to take off men's shoes and to wash their feet when they came home, and they had to kiss the men's hands, no matter what their age. After cooking the meal, women had to serve the men at the table and were only allowed to eat what was left after the men had finished. And if a man found a woman sitting, she had to stand up (Rakitsch 17-19). To sum up Rakitsch's view: women were necessary in Sadruge merely for their labor power and for reproduction.

\section{AN “OTHER” OF THEIR OWN}

With the scientific "discovery" or "invention" of the zadruga in the nineteenth century, the binding of the zadruga to national myth-making discourses commenced. In the course of these processes, it was not really of importance whether or not the zadruga had ever existed or - as Maria Todorova has put it 
- whether it had merely had a "literary life." ${ }^{30}$ What was important were the intentions of the respective authors: the zadruga served them mainly as examples and illustrations of their arguments.

As legal experts, Utješenović, Bogišić and Strohal were, naturally, primarily interested in the legal aspect of the topic. Their occupation with the Hauskommunionen/zadruge and the laws governing them was not in the least due to their dissatisfaction with the ignorance of Austrian, Hungarian and Serbian lawmakers - the latter being influenced and inspired by Roman-German jurisdiction - regarding zadruga common law. Annoyance united Utješenović, Bogišić and Strohal and fulfilled a valuable function: it proved the "cultural inability" of non-Southern Slavs to comprehend the mechanisms of living together in a typically South Slavic social institution. In the same way, Rakitsch's professional training as a teacher and her university education in pedagogy determined the choice of her subject and suggested "domestic education in the zadruga" as a topic for her doctoral thesis. Her judgment of this education turned out to be rather disapproving.

In the history of writing on the zadruga, many examples show that the zadruga has been used for raising an immense range of crucial political and cultural questions, for instance, when in the young socialist state of Yugoslavia the previous writings on the topic of zadruga were analyzed with the methods of historical materialism; ${ }^{31}$ or when at the end of the 1970 s the role of the zadruga for emigration was examined; ${ }^{32}$ or - as a last example - when the zadruga was made responsible for the wars in the former Yugoslavia in the 1990s. ${ }^{33}$

I have tried to show some of the main issues authors with a South Slavic perspective were occupied with when writing on the topic of the zadruga from the middle of the nineteenth century up to 1914. I have found that these texts contributed to the construction of a peculiar South Slavic "Other." South Slavic nation-building processes were oriented along Western concepts of nationhood; in order to for their nation-building efforts to succeed, Southern Slavs had to show both resemblance to as well as distinction from the West. The zadruga seems to have been an ideal site for such a discourse. It could be interpreted as a social institution whose inner logic was formed by solidarity and was therefore completely unknown and incomprehensible to "Western individualists" or - with more proximity to the West - just classified as a backward stage in the "anthropological development" of family types, which the West already had overcome. By means of the zadruga, categories like "Balkan," "patriarchal" or "extended family" could be negotiated and, when found to be unfavorable for Southern Slavs, firmly rejected. Consequently, moving towards and moving away from the West were expressions of an ambivalence whose extreme poles manifest themselves in the following way: on the one hand, in comparison to 
the West, the zadruga appears hopelessly backward; on the other hand, it can serve the West as a model.

\section{REFERENCES}

Andrejić, Ljubomir. "Bibliografija o porodičnoj zadruzi kod naših naroda." Glasnik etnografskog muzeja 36 (1973): 191-290.

Bogišić, V[altazar]. De la forme dite inokosna de la famille rurale chez les Serbes et les Croates. Paris, 1884.

-. O obliku nazvanom inokoština u seoskoj porodici Srba i Hrvata. Beograd, 1884.

Ehrlich-Stein, Vera. "The Southern Slav Patriarchal Family." The Sociological Review 32.3-4 (1940): 224-41.

Filipović, Milenko. "Zadruga (Kaćna [sic] zadruga)." Communal Families in the Balkans: The Zadruga. Essays by Philip E. Mosely and Essays in His Honour. Ed. Robert F. Byrnes. Notre Dame; London: University of Notre Dame Press, 1976. 268-79.

Filipović-Fabjanović, Radmila. "Porodična zadruga i njen značaj za ekonomsku emigraciju." Glasnik Zemaljskog muzeja Bosne i Hercegovine u Sarajevu 32 (1978): 183-94.

Gavazzi, Milovan. "Die Erforschung der Mehrfamilien Südosteuropas in den letzten Dezennien." Südosteuropa und Südosteuropa-Forschung. Zur Entwicklung und Problematik der Südosteuropa-Forschung. Ed. Klaus-Detlev Grothusen. Hamburg: Vandenhoeck \& Ruprecht, 1976. 143-6.

Karadžić, Vuk Stefanović. Srpski riječnik istumačen njemačkim i latinskim riječima. 2nd ed. U Beču: Mechitaristicae, 1852.

-. Srpski rječnik istolkovan njemačkim i latinskim riječima. Beč: Bei den P.P. Armeniern, 1818. Karl Kaser, Familie und Verwandtschaft auf dem Balkan. Analyse einer untergehenden Kultur. Wien: Böhlau, 1994.

Kulišić, Špiro. "O postanku slovenske zadruge." Bilten instituta za proučavanje folklora 3 (1955): 43-55.

Mandić, Oleg. "Klasni karakter buržoaskih teorija o postanku zadruge." Istorisko-pravni Zbornik 2.3-4 (1950): 131-55.

Popović, Vasilj. Zadruga. Istorijska rasprava. Sarajevo: Zemaljska štamparija, 1921.

-. Zadruga. Teorije i literatura. Sarajevo: Zemaljska štamparija, 1922.

Puhar, Alenka. "On Childhood Origins of Violence in Yugoslavia: The Zadruga." The Journal of Psychohistory 21.2 (1993): 171-97.

Rakitsch, Ljubiza. "Die häusliche Erziehung in der serbischen Sadruga [sic] zur Zeit der türkischen Herrschaft." Inaugural-Dissertation zur Erlangung der Doktorwürde der hohen philosophischen Fakultät I der Universität Zürich. Leemann \& Co, 1914.

Rihtman-Auguštin, Dunja. Struktura tradicijskog mišljenja. Zagreb: Školska knjiga, 1984.

-. "Zur Theorie des südslawischen Familiensystems Zadruga." Jahrbuch für Volkskunde N.F. 7 (1984): 71-80.

Scott, Joan W. Only paradoxes to offer. French Feminists and the Rights of Man. Cambridge; London: Harvard University Press, 1996.

Strohal, Ivan. "Zadruge u južnih Slovjena." Glasnik zemaljskog muzeja u Bosni i Hercegovini 21 (1909): 215-96.

Todorova, Maria. Balkan Family Structure and the European Pattern. Demographic Developments in Ottoman Bulgaria. Washington, D.C.: The American University Press, 1993. 
--.. "Myth-Making in European Family History: The Zadruga Revisted." European Politics and Societies 4.1 (1990): 30-76.

Utiešenović, Og[njeslav] M. Die Hauskommunionen der Südslaven. Eine Denkschrift zur Beleuchtung der volksthümlichen Acker-und Familienverfassung des serbischen und kroatischen Volkes. Wien: F. Manz \& Compagnie, 1859.

Utješenović Ostrožinski, Ognjeslav. Kućne zadruge/Vojna Krajina. Zagreb: Školska knjiga, 1988.

\section{ENDNOTES}

${ }^{1}$ This article is based on a paper given at the "South-Eastern Europe - Concepts, Histories, Boundaries" conference organized by the Center for South-East European Studies, School of Slavonic and East European Studies (University of London) in June 1999. My thanks go to the Austrian Ministry for Science and Culture, which funded my presentation in the framework of its Cultural Studies program.

${ }^{2}$ This immense interest is reflected by an article published in 1973, when Ljubomir Andrejić had put together an annotated bibliography on the zadruga, which was almost one hundred pages long. Ljubomir Andrejić, "Bibliografija o porodičnoj zadruzi kod naših naroda," Glasnik etnografskog muzeja 36 (1973): 191-29o.

${ }^{3}$ I am emphasizing the zadruga as a family type since the word zadruga has many other meanings, such as co-operative, society, association, union, guild.

${ }^{4}$ Referring to Karadžić's significance and the discussions of the origin and duration of the zadruga phenomenon, Maria Todorova pointed out that "(a)lthough it is asserted that 'the South-Slav zadruga is occasionally mentioned in written sources as early as the twelfth century' (Filipović, 1976: 269), it must be kept in mind that this is an interpretative assertion. The term [...] was unknown until the nineteenth century, and what was accepted as zadruga was the interpretation of certain evidence as proof of the existence of complex families" (Original italics). Maria Todorova, Balkan Family Structure and the European Pattern. Demographic Developments in Ottoman Bulgaria (Washington, D.C.: The American University Press, 1993) 140. Todorova is quoting the following work here: Milenko Filipović, "Zadruga (Kaćna [Sic] Zadruga)," Communal Families in the Balkans: The Zadruga. Essays by Philip E. Mosely and Essays in His Honour, ed. Robert F. Byrnes (Notre Dame; London: University of Notre Dame Press, 1976). In an earlier article Todorova even attributed to the zadruga a merely "literary life." Maria Todorova, "Myth-Making in European Family History: The Zadruga Revisted," European Politics and Societies 4.1 (1990). 64.

${ }^{5}$ V[altazar] Bogišić, De la forme dite inokosna de la famille rurale chez les Serbes et les Croates (Paris: 1884) 36.

${ }^{6}$ In Serbo-Croatian/Serbian/Croatian, there are two expressions for the verb "to marry." Udati se refers to women and carries in its core the verb give (dati). When men marry, usually the verb oženiti se is applied, which contains the word for woman - žena. Karadžićs use of the male verb for marrying might be due to the common custom that girls and young women born in a zadruga ought not to stay with their families but married into the zadruga of their groom. Boys and young men, on the other hand, were supposed to continue living with their family in the zadruga where they had been born and had grown up.

7 "Po triestoro čeljadi slušao sam u Srbiji da se nalazi u jednoj kući; ali su mi u Dalmaciji u Kosovu pokazivali čoveka iz sela Ridjani, po prezimenu Trifunovića, koji ima šezdeset i dvoje čeljadi, medju kojom je trinaest žena s muževima i dvije udovice. O božiću i o krsnom imenu i kad koga žene sastanu se svi u kući, a onako žive po planinama i po polju, a starješina ponajviše u mlinu. Ova kuća ima oko hiljadu i četiri stotine koza i ovaca, do pedeset goveda i četrnaest konja [...]." Unless otherwise noted, all translations are mine. 
${ }^{8}$ Almost 130 years after the German original, Utješenović's monograph was translated into Serbo-Croatian together with another one of his important texts: Ognjeslav Utješenović Ostrožinski, Kućne Zadruge/Vojna Krajina (Zagreb: Školska knjiga, 1988). I here render Utješenović's surname according to current Croatian spelling and consequently spell it Utješenović instead of Utiešenović.

${ }^{9}$ A Serbian version of tBogišićs already mentioned book came out in the same year - 1884 in Belgrade: V[altazar] Bogišić, O obliku nazvanom inokoština u seoskoj porodici Srba i Hrvata (Beograd: 1884). Rather striking is the fact that the translator of Bogišić's French treatise, Jovan Aćimović, employed the noun inokoština in the very title of the book, given that one of Bogišić's main arguments was that the words zadruga and inokoština did not exist, but people used the formulations inokosna kuća as well as zadružna kuća.

${ }^{10}$ Note that Strohal was the only one of these four writers writing in Croatian.

${ }^{11}$ There was hardly any investigation of the zadruga in the inter-war period. One of the few exceptions was Vasilj Popović's work in two parts: Vasilj Popović, Zadruga. Teorije i literatura (Sarajevo: Zemaljska štamparija, 1922), Vasilj Popović, Zadruga. Istorijska rasprava (Sarajevo: Zemaljska štamparija, 1921). Vera Erlich, who conducted her research on the zadruga in the late 1930s, published only one article on this topic in the inter-war period: Vera Ehrlich-Stein, “The Southern Slav Patriarchal Family, The Sociological Review 32.3-4 (1940).

${ }^{12}$ The fact that only one woman published something on the zadruga until the First World War is, in my opinion, in no way due to a female lack of scientific or writing competence - nor is it a peculiarity to South-Slav research on zadruge. Rather it is the result of exclusionary social, economic and - for a long time - also legal mechanisms. The example of Ljubiza Rakitsch shows that even when women were finally admitted to universities and even when a woman did write on the zadruga, hardly any attention was paid to it. Although or just because I did not find her to be cited or referred to even once, I decided to work with her text in order not to reproduce this exclusion in academic discourses on the zadruga.

${ }^{13}$ I am borrowing this very apt description from another case-study: Joan W. Scott, Only Paradoxes to Offer. French Feminists and the Rights of Man (Cambridge; London: Harvard University Press, 1996) 16.

${ }^{14}$ The first written accounts of a family type later identified by zadruga-researchers as $z a$ druga date from the middle of the eighteenth century and are ascribed to the writers Matija Antun Reljković and Ivan Lovrić as well as to the travellers Mathias Piller and Ludwig Mitterpacher. Milovan Gavazzi, "Die Erforschung der Mehrfamilien Südosteuropas in den letzten Dezennien," Südosteuropa und Südosteuropa-Forschung. Zur Entwicklung und Problematik der Südosteuropa-Forschung, ed. Klaus-Detlev Grothusen (Hamburg: Vandenhoeck \& Ruprecht, 1976), Dunja Rihtman-Auguštin, Struktura tradicijskog mišljenja (Zagreb: Školska knjiga, 1984).

${ }_{15}$ "[...] nicht einseitig und nicht etwa in einem engherzigen Lokalpatriotismus oder in dem Nebel der historischen politisch-sentimentalen Rückerinnerung befangen [...]."

16 "Gewöhnlich in einem förmlichen Haine von Obstbäumen steht ein nicht zu grosses Haus, das meistens ein Vorhaus hat, aus dem man in den Raum der Küche oder Feuerstelle und rechts und links in geräumige Zimmer tritt, die in wohlhabenden Ortschaften ganz wohnlich und reinlich, in aermern dagegen wohl auch sehr armselig eingerichtet sind. [...] In einem solchen mit dem Taufnamen des Hausvaters und einem einzigen Familiennamen benannten Hause findet man gewöhnlich:

1. einen rüstigen Hausvater (gospodar, starešina) von 40-50 Jahren mit seinem Eheweibe und 2-3 Kindern; der erstere ist mit dem Amte des Verwalters dieses ganzen Hauses betraut, wogegen ihn sein Weib in Bezug auf das innere Hauswesen unterstützt; 
2. seine alten 6o-70jährigen Eltern, der Vater war früher Hausvater, hat aber diese Bürde zurückgelegt;

3. seines Vaters Bruder mit seinem Eheweib mit oder ohne welche Kinder;

4. einen jüngeren Bruder des Hausvaters mit seinem Eheweibe;

5. ein jüngeren Bruder desselben ist etwa als Soldat abwesend.

Neben dem Hause stehen Stallungen für die verschiedenen Viehgattungen [...] sammt dem nöthigen Feld und Hausgeräthe und den erfoderlichen Wirtschaftsgebäuden.

Die Grundansässigkeit hat 25-40 Joch in mehr oder minder zerstreuten Grundparzellen, da die Dorfgemengewirthschaften vorwiegen." (italics in original).

${ }^{17}$ In Bogišić's own eyes this made him one of the strongest defenders of the zadruga: "Parmi les défenseurs de la zadruga, le plus énergique a été certainement Utiešenovi_." Bogišić, De la forme 2 footnote 1 . See the following passage for Bogišić's own accounts of the zadruga.

18 "Die Arbeit ist ein Fest; den ganzen Tag wird gesungen, und Abends, wenn man glaubt, die Leute wären von dem langen Tagwerke eines Sommertages müde, fängt das lustige junge Volk einen Kolo-Tanz an."

${ }_{19}$ This phrasing excludes any possible existence of, for instance, Muslims or Jews living in Hauskommunionen. Not only does it seem to have been unthinkable for Utješenović that Muslims would have lived in Hauskommunionen, he also believed the "Christian-Slav people" had found backing in Hauskommunionen under the "Turkish yoke." It seems reasonable to suspect that the author viewed Hauskommunionen as a measure to assure the continuity of national identityy (Utiešenović, Die Hauskommunionen 45).

20 "Zapadnjaci nijesu prema toj teoriji bili sasma nesposobni za ovakove uredbe, kakove postoje u slovjenskih naroda; oni su se samo iskvarili, i moraju se popraviti. Taj popravak, tu regeneraciju zapadnih naroda imali bi pak provesti istočni slovjenski narodi; i to ne slovjenske državne vlasti, nego neiskvareni slovjenski narod."

${ }_{21}$ "[D]a su ove uredbe plod blage altruističke čudi slovjenskih naroda [...]."

${ }^{22}{ }^{2}[\ldots]$ zemljište $[\ldots]$ ne pripada niti pojedincu izmegju njih kao samovlastniku niti svima njima kao suvlasnicima, nego samo svrsi čitave imovine, kao posebnoj jurističkoj osobi. [...] [U] zadruzi nije vlasnikom zadružne imovine niti kućegospodar niti drugi koji zadrugar nego samo čitava porodica kao posebna juristička osoba."

${ }_{23}$ "Unter Sadruga versteht man den Zusammenschluß einer Anzahl durch Blutsverwandtschaft miteinander verbundenen Familien zu einer einzigen Großfamilie mit gemeinsamen Eigentum. Die Sadruga umfaßt nicht selten über 40 und 50 Mitglieder. [...] Die Sadruga weist durchaus den Charakter einer patriarchalen Familienform auf. An der Spitze der Gesamtfamilie stand das Oberhaupt, gewöhnlich das älteste Mitglied - Starešina oder Domaćin genannt.” ${ }_{24}$ "[D]ie Stellung der Frau in der patriarchalen serbischen Familie, die zu derjenigen in höher entwickelten Kulturen in schroffem Gegensatz steht."

${ }_{25}$ "[Z]iemlich beschränkt. Von einer sklavischen Unterordnung der anderen Familienmitglieder war keine Rede."

26 "[V]erpflichtet, sich den Anordnungen des Hausältesten völlig zu fügen."

${ }^{27}$ The sociologist and cultural historian Wilhelm Heinrich Riehl (1823-1897) coined the German term "Ganzes Haus" in his book Die Familie (1854). On the influences of Riehl on Utješenović, see: Dunja Rihtman-Auguštin, "Zur Theorie des südslawischen Familiensystems Zadruga," Jahrbuch für Volkskunde N.F. 7 (1984).

${ }^{28}$ Since the 1990 os the historian Karl Kaser has been publishing intensively on the topic of the "Balkanfamilie" or "Balkanfamilienhaushalt" as he calls his subject. Kaser rejects the term zadruga for four reasons: 1) because the South Slavic word zadruga suggests that the Balkanfamilie is limited to the South Slav population; 2) because the term zadruga was misused for a national myth by both the Serbian and Croatian sides; 3) because zadruga was wrongly iden- 
tified with the idea of an extended family;and finally 4) because zadruga was used for designating any complex family structure in South-Eastern Europe without analyzing specific cultural patterns (Karl Kaser, Familie und Verwandtschaft auf dem Balkan. Analyse einer untergehenden Kultur (Wien: Böhlau, 1994) 37f.) Considering Kaser's choice the terms Balkanfamilie/ nhaushalt, as well as some of his results, his arguments against the term zadruga are rather surprising. He responds to what he calls a "national myth" with a scholarly myth. Referring to the extended family Kaser criticizes:

"It is hard to imagine how households with over one hundred housemates could be organized. In the first half of the $19^{\text {th }}$ century households of 100,150 and even 250 persons are supposed to have existed in Western Bulgaria. [... In the second half of the $19^{\text {th }}$ century households became smaller and rarely exceeded 60 housemates, and at the beginning of the $2 \mathrm{o}^{\text {th }}$ century they were hardly more extensive than 20 - 30 persons. Today the most extensive Balkanfamilienhaushalte are to be found in Kosovo. In the last decades some households existed, which had more than 100 housemates; one still exists today. Compared with them, complex households in the military frontier were very small. In the $19^{\text {th }}$ century hardly any existed that included more than $15-25$ housemates." (Kaser, Familie und Verwandtschaft 341f.)

(„Es ist schwer vorstellbar, wie Haushalte, die über hundert Mitglieder umfaßten, organisiert werden können. In Westbulgarien soll es in der ersten Hälfte des 19. Jahrhunderts Haushalte mit 100, 150 und sogar 250 Personen gegeben haben. [...] In der zweiten Hälfte des Jahrhunderts wurden die Haushalte kleiner und überstiegen selten die Zahl von 6o Mitgliedern, und zu Beginn des 20. Jahrhunderts waren sie kaum umfangreicher als 20 bis 30 Personen. Die heute umfangreichsten Ballkanfamilienhaushalte befinden sich im Kosovo. In den letzten Dezennien gab es einige Haushalte, die über 100 Mitglieder stark waren, einer existiert noch heute. Die komplexen Haushalte in der Militärgrenze waren, damit verglichen, sehr klein. Im 19. Jahrhundert gab es kaum welche, die mehr als 15 bis 25 Mitglieder umfaßten.")

I reckon Kaser's scientific occupation and his texts to be building on the construct of the "Balkan, patriarchal extended family" and reconstructing it.

${ }^{29}$ Utješenović was by far not the only one predominantly led by his ideas about normative gender relationships. In none of the four texts are such phenomena mentioned as the domazet or domazetstvo, where the son-in-law moved into and lived in the zadruga of his bride/wife, or the virdžin, muškobana or tobelija, in English known as the sworn virgin, a girl or woman who because of the lack of a man in her generation of the family decides to live as a man and thereby ensures the patriarchality of her family.

${ }^{30}$ Todorova, "Myth-Making," 64.

${ }^{31}$ Špiro Kulišić, "O postanku slovenske zadruge," Bilten instituta za proučavanje folklora 3 (1955), Oleg Mandić, “Klasni karakter buržoaskih teorija o postanku zadruge," Istorisko-pravni Zbornik 2.3-4 (1950).

${ }^{32}$ Radmila Filipović-Fabjanović, "Porodična zadruga i njen značaj za ekonomsku emigraciju," Glasnik Zemaljskog muzeja Bosne i Hercegovine u Sarajevu 32 (1978).

${ }_{33}$ Alenka Puhar, "On Childhood Origins of Violence in Yugoslavia: The Zadruga," The Journal of Psychohistory 21.2 (1993).

Natascha Vittorelli studied history and South Slavic languages and literatures in Vienna and Barcelona. She currently holds a DOC-Fellowship with the Austrian Academy of Sciences, working on a PhD-thesis on the history of the first women's movements in the South Slavic areas of the Habsburg monarchy. 